\title{
Tissue Retention and Adverse Reaction after Intravenous Injection of Hematoporphyrin Derivatives in Dogs
}

\author{
Yoshiharu OKAMOTO ${ }^{1)}$, Daisuke YONEMURA ${ }^{1)}$, Katsuyuki MIYATAKE ${ }^{1)}$, Yasuo HASHIMOTO ${ }^{2)}$, Toru HIRANO ${ }^{3)}$, \\ Isao SAKATA ${ }^{4)}$ and Saburo MINAMI ${ }^{1)}$ \\ ${ }^{1)}$ Department of Veterinary Surgery, Faculty of Agriculture, Tottori University, 101 Minami 4-chome, Koyama-cho, Tottori 680-8553, \\ ${ }^{2)}$ You-linn Hospital, 2-15-38, Funabashi, Setagaya, Tokyo 156-0055, ${ }^{3)}$ Photon Medical Research Center, Hamamatsu University School \\ of Medicine, 3600 Handa-cho, Hamamatsu 431-3192 and ${ }^{4)}$ Photochemical Co., Ltd., 5301 Haga, Okayama 701-1221, Japan
}

(Received 4 May 2004/Accepted 27 July 2004)

ABSTRACT. We evaluated changes in hematology and chemical profile, and the tissue retention of hematoporphyrin derivative (HpD) following the intravenous injection in dogs. $\mathrm{HpD}$ at concentrations of $1,5,10$, and $15 \mathrm{mg} / \mathrm{kg}$ was intravenously injected to $16 \mathrm{dogs}$ ( $\mathrm{n}=4$ each) and complete blood count (CBC) and blood chemistry were performed on days 1, 3, 5, and 7 after the injection. To examine tissue retention, $\mathrm{HpD}(5 \mathrm{mg} / \mathrm{kg})$ was administered to $15 \mathrm{dogs}$ and $3 \mathrm{dogs}$ were euthanized on days $1,2,7,14$, and 28 after the injection, respectively, to collect the skin, muscle, small intestine, spleen, kidney and liver as tissue samples. There were no significant changes in CBC and blood chemical profile except for an increase in LDH concentrations in dogs given 10 and $15 \mathrm{mg} / \mathrm{kg}$ of $\mathrm{HpD}$ at day 3 . The levels of $\mathrm{HpD}$ retention in the tissues were ranked in the following order: liver $>$ kidney $>$ spleen $>$ intestine $>$ muscle $>$ skin.

KEY WORDS: canine, hematoporhyrin D, photodynamic therapy.

J. Vet. Med. Sci. 66(12): 1599-1601, 2004

Photodynamic therapy (PDT) is a treatment modality for tumors using laser irradiation with a photosensitizer, and has recently been paid attention in human and veterinary medicine $[11,18]$. In PDT, the photosensitizer is initially administered topically or systemically. The drug is expelled from the normal tissue over a period of days but remain in the tumor tissue because of the lack of normal exhaust functions via lymph nodes or others. In the next, red laser light that matches the photosensitizer's absorption is irradiated to the tumor, then the activated photosensitizer produces free radicals within the tumor tissue that cause tumor cell death [13]. The most common photosensitizer is hematoporphyrin derivative $(\mathrm{HpD})$. There have been many descriptions of the tissue retention and side effects of $\mathrm{HpD}$ in rodent models [2, 4, 7-9]. Hepatoxity and sunlight-induced dermatitis due to prolonged tissue retention [14] have been pointed out as side effects of HpD. PDT seems to be useful modality, and there have been some reports on the application of HpD for spontaneous tumors in dogs and cats $[3,6,19]$, however as far as we know there have been no reports on the side effects of $\mathrm{HpD}$ in these animals. More detailed information will be required for the application of PDT in the veterinary field.

In this study, we evaluated retention of $\mathrm{HpD}$ in the tissues and the adverse effects of $\mathrm{HpD}$ on hematology and blood chemical profile in dogs.

Photosensitizer: Hematoporphyrin derivative (HpD: Queen Elizabeth Hospital, Australia) as a photosensitizer was stored at $-20^{\circ} \mathrm{C}$, and was warmed up to $37^{\circ} \mathrm{C}$ immediately before injection.

Animals: Thirty-one mongrel dogs, with the age from 1 to 3 years and weight from 5 to $15 \mathrm{~kg}$ were used in this study. Sixteen of the $31 \mathrm{dogs}$ were used to assess hematological and blood chemical profiles and the remaining 15 dogs were used to examine the tissue retention property of $\mathrm{HpD}$. These animals were healthy on clinical and hematological examinations. Animals were kept in a dark room to prevent the development of sunlight-induced dermatitis during the experimental period. Animal treatments were performed according to the guidelines for Animal Experimentation of the Faculty of Agriculture of Tottori University, the Japanese Government Animal Protection and Management Law (No. 105), and the Japanese Government Notification on the Feeding and Safekeeping of Animals (No. 6), with the permission of the Animal Committee of the Faculty of Agriculture of Tottori University (approval No. 2001-1).

Blood examination: Sixteen animals were divided into 4 groups of 4 dogs each and intravenously injected with $\mathrm{HpD}$ at concentrations of $1,5,10$ and $15 \mathrm{mg} / \mathrm{kg}$, respectively. Heparinized blood was collected from the jugular vein before (Pre) and at days 1, 3, 5, and 7 after administration of HpD. Blood cell count and hemoglobin concentration were measured with an automatic cell counter (Celtack, Nihon Koden, Tokyo). Blood chemistry was performed using a Cobas Ready dry chemistry system (Japan Roche, Tokyo) for the following parameters: D-glucose, total cholesterol, blood urea nitrogen, alkaline phosphatase, aspartate aminotransferase, alanine aminotransferase, creatinine phosphokinase, creatinine, calcium, albumin, total bilirubin, amylase, triglyceride, and lactate dehydrogenase. Statistical analysis was performed by the paired $t$-test with Stat View 4.5 software (Abacus Concepts, U.S.A.) for Macintosh.

Tissue retention: Fifteen dogs received $5 \mathrm{mg} / \mathrm{kg}$ of $\mathrm{HpD}$ intravenously. This dose is commonly used in the previous reports $[3,6,19]$. On days $1,2,7,14$, and 28 after the injection, 3 dogs were euthanized and the skin, muscle, small intestine, spleen, kidney and liver were collected. These samples were stored at $-80^{\circ} \mathrm{C}$ until analysis.

The tissue sample of $1 \mathrm{gm}$ was mixed with $3 \mathrm{~m} l$ acetone 
in a $50-\mathrm{m} l$ beaker, and $3 \mathrm{~m} l$ of acetone was added and minced with scissors. The acetone extract of $\mathrm{HpD}$ was filtered using Whatmann filter paper. The same volume of acetone was added to the beaker again and HpD was extracted similarly. The weight of the HpD extract solution was adjusted to $5 \mathrm{~g}$ with acetone. The $\mathrm{HpD}$ concentration was measured by high-performance liquid chromatography (HPLC) (RF-10AXL, Shimazu, Kyoto) under the following analytical conditions: column, Intersil ODS-2 (4.6 mm ID x $150 \mathrm{~mm}$ ); eluent, THF: Hexane $=1: 1$; exited wave, $400 \mathrm{~nm}$; fluorescence wave, $630 \mathrm{~nm}$; flow rate, $0.5 \mathrm{ml} / \mathrm{min}$.

Several peaks were detected in the HPLC assay, but almost all the peaks were absorbed at $400 \mathrm{~nm}$. Therefore, we measured the HpD level in the tissue using a spectrophotometer (UV-120-01, Simazu, Kyoto) at $400 \mathrm{~nm}$.

The appetite, vigor, and general physical conditions were normal on any days in all groups. In hematological and blood chemical findings, no significant changes were observed in all parameters except for lactic dehydrogenase $(\mathrm{LDH})$ in any of the groups. As shown in Fig. 1, LDH levels exceeded above the normal range in dogs injected with 10 and $15 \mathrm{mg} / \mathrm{kg} \mathrm{HpD}$ at day 3, but they returned to the normal range at day 5 .

Figure 2 shows the changes in $\mathrm{HpD}$ level in each tissue. The HpD level in the tissues rapidly decreased on day 2 to about half of those on day 1 except for the intestine, in which HpD level increased on days 2. On day 7, the HpD level in the tissues decreased to about one-third of those on day 1 except for the liver, in which the HpD level increased to the similar level of day 1 . After day 7 , the rate of decrease in tissue HpD content was slow in all tissues. On day 28, $\mathrm{HpD}$ remained at various concentrations in all tissues. The retention of $\mathrm{HpD}$ was ranked into the following order: liver
$>$ kidney $>$ spleen $>$ intestine $>$ muscle $>$ skin. The HpD level in the skin on day 28 was $0.4 \mu \mathrm{g} / \mathrm{g}$ tissue, while that in the liver was $18.8 \mu \mathrm{g} / \mathrm{g}$ tissue.

The present study indicated that the administration of

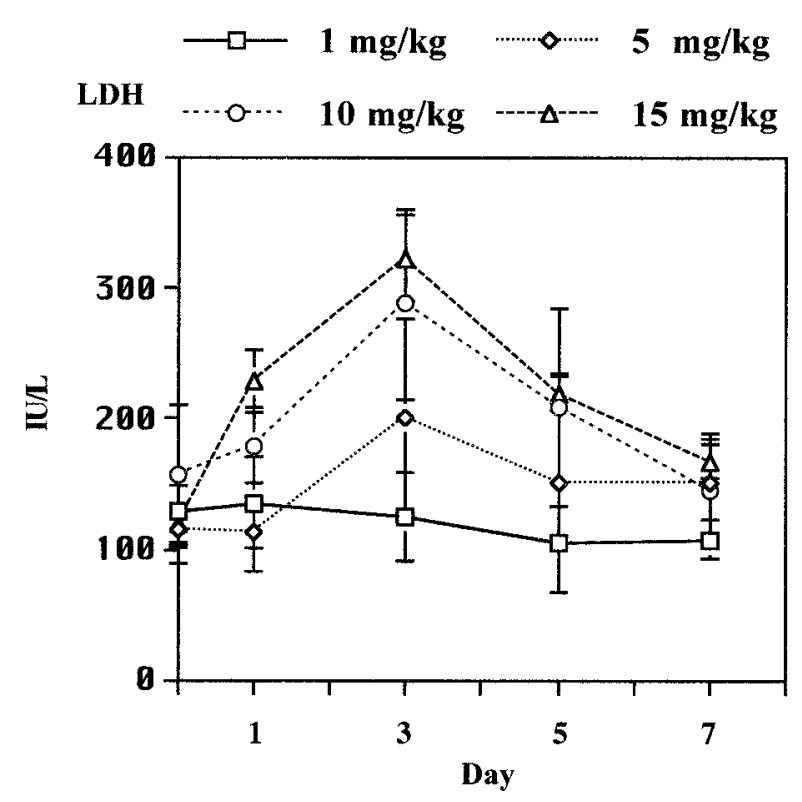

Fig. 1. Changes in plasma LDH level in dogs. Sixteen animals were divided into 4 groups of $4 \mathrm{dogs}$ each and intravenously injected with $\mathrm{HpD}$ at concentrations of $1,5,10$ and $15 \mathrm{mg} / \mathrm{kg}$, respectively. LDH levels exceeded the normal range in dogs injected with $10 \mathrm{mg} / \mathrm{kg}$ and $15 \mathrm{mg} / \mathrm{kg} \mathrm{HpD}$ at day 3 , but the level returned to the normal range at day 5 .

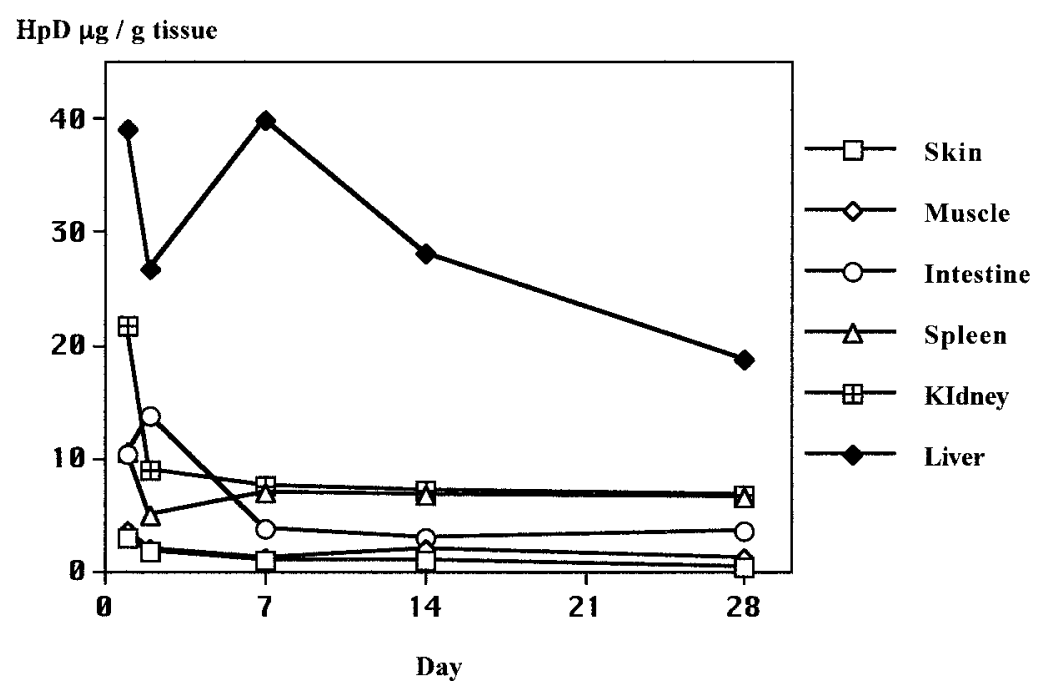

Fig. 2. Changes in the $\mathrm{HpD}$ level in each tissue. Fifteen dogs received $5 \mathrm{mg} / \mathrm{kg}$ of $\mathrm{HpD}$ intravenously. On day $2, \mathrm{HpD}$ levels of tissues except for the intestine decreased to half of those on day 1 . After day 7, the decreaseing rate was slow in most tissues. On day 7, the $\mathrm{HpD}$ level in the liver increased to that on day 1. On day 28, the HpD level in the skin was $0.4 \mu \mathrm{g} / \mathrm{g}$ tissue. 
$\mathrm{HpD}$ at a concentration of less than $10 \mathrm{mg} / \mathrm{kg}$ did not influence the general physical conditions, hematological findings, and blood chemical profiles in dogs. This administration level was similar to that usually used for human [5].

The results of tissue retention were mostly consistent with the previous reports in rodent models [2, 4, 7-9]. In the previous reports, however, the $\mathrm{HpD}$ level in the skin was higher than that in the muscle in mice. One potential reason for this may be a difference between species in the initial uptake of HpD in each tissue. Skin is one of the most common sites of tumors in animals [12]. Therefore, it is important to understand retention of $\mathrm{HpD}$ in the skin. On day 28, the level of residual $\mathrm{HpD}$ in $1 \mathrm{~g}$ of the canine skin tissue was about $0.4 \mu \mathrm{g}$. This indicates the importance not to expose the animal to sun light for at least one month after the HpD injection. In human, $\mathrm{HpD}$ remained for over one month after a systemic injection of $2.5 \mathrm{mg} / \mathrm{kg} \mathrm{HpD}$, because severe redness and edema of the skin induced by light exposure was observed at 3 weeks after the injection [5].

The present study showed that $\mathrm{HpD}$ accumulated predominantly in the liver, spleen and kidney. HpD accumulates in reticuloendothelial cell components including Kupffer cells in the liver, alveolar macrophages, splenic sinus macrophages, and intraglomerular mesangial cells in the kidney [1]. The present result supports these previous data. Regarding the distribution of $\mathrm{HpD}$ in the liver, its $\mathrm{HpD}$ level showed a second increase on day 7. A similar tendency was also noted in the previous reports [15-19, 20]. This suggests that $\mathrm{HpD}$ was excreted into the intestine as bile, which was reabsorbed from the intestine. In view of the prolonged retention of $\mathrm{HpD}$ in the liver observed in this report, we must pay great attention to the application of $\mathrm{HpD}$ to animals with liver dysfunction.

HpD contains hematoporphyrin (HP) and dehydrated HP products [10]. It is indicated that plasma binding and the capacity for cell uptake differ among products. However, there have been no data on the residual products in the tissue. In the future it will be necessary to investigate which components of $\mathrm{HpD}$ remain for 28 days after the $\mathrm{HpD}$ injection.

In the reports of Kessel et al. [10], the HpD level was measured by HPLC [10], a method using a radioactive material [7], and nitrogen-pulsed laser spectrofluorometry $\left(\mathrm{N}_{2-}\right.$ PLS) $[15,16]$. While $\mathrm{N}_{2}$-PLS has been pointed out to be less efficient in the quantitative analysis, it can be recommended for its very high simplicity. Regarding use of radioactive material, HpD labeling is difficult to accomplish as HpD is an agent extracted from the blood of pigs. The data from preliminary studies were obtained by spectrophotometery as well as by HPLC. We measured the level of HpD by spectrophotometry.

\section{REFERENCES}

1. Bellnier, D. A. and Henderson, B. W. 1992. pp. 117-127. In: Photodynamic Therapy (Henderson, B. W. and Dougherty, T. J. eds.), Marcel Dekker, Inc., New York.

2. Bugelski, P. J., Porter, C. W. and Dougherty, T. J. 1981. Cancer Res. 41: 4606-4612.

3. Cheli, R., Addis, F., Mortellaro, E. M., Fonda,D., Andreoni, A. and Cubeddu, R. 1984. Cancer Letters 23: 61-66.

4. Dougherty, T. J., Grindey, G. B., Fiel, R., Weishaupt, K. R. and Boyle, D. G. 1975. J. Nat. Cancer Inst. 55: 115-121.

5. Dougherty, T. J., Kaufman, J. E., Goldfarb, A., Weishaupt, K. R., Boyle, D. G. and Mittleman, A. 1978. Cancer Res. 38: 2628-2635.

6. Dougherty, T. J., Thoma, R. E., Boyle, D. G. and Weishaupt, K. R. 1981. Cancer Res. 41: 401-404.

7. Gomer, C. J. and Dougherty, T. J. 1979. Cancer Res. 39: 146151.

8. Gomer, C. J. and Razum, N. J. 1984. Photochem. Photobiol. 40: $435-439$

9. Kaye, A. H., Morstyn, G. and Ashcroft, R. G. 1985. Neurosurgery 17: 883-890.

10. Kessel, D., Byrne, C. J. and Ward, A. D. 1992. pp. 129-143. In: Photodynamic Therapy (Henderson, B. W. and Dougherty, T. J. eds.), Marcel Dekker, Inc., New York.

11. Lucroy, M. D., Edwards, B. F. and Madewell, B. R. 2000. J. Am. Vet. Med. Assoc. 216: 1745-1751.

12. Madewell, B. R. and Theilen, G. H. 1987. pp. 233-325. In: Veterinary Cancer Medicine 2nd ed. (Madewell, B. R. and Theilen, G. H. eds.), Lea \& Febiger, Philadelphia.

13. Magne, M. L. 1998. pp. 469-476. In: Cancer in Dogs and Cats (Morrison, W. B., ed.), Lippincott Williams \& Wilkins, Philadelphia.

14. Marcus, S. L. 1992. pp. 219-268. In: Photodynamic Therapy (Henderson, B. W. and Dougherty, T. J. eds.), Marcel Dekker, Inc., New York.

15. Nakajima, S., Hayashi, H., Omote, Y., Yamazaki, Y., Hirata, S., Maeda, T., Takemura, T., Kakiuti, Y., Sindo, Y., Koshimizu, K. and Sakata, I. 1990. J. Photochem. Photobiol. B: Biol. 7: 189-198.

16. Nakajima, S., Sakata, I., Omote, Y., Yamazaki, Y., Maeda, T., Kubo. Y., Samejima, N., Takemura, T., Sindo, Y., Yamauti, H. and Koshimizu, K. 1991. J. Photochem. Photobiol. B: Biol. 8: 409-417.

17. Nakajima, S., Sakata, I., Takemura, T. and Hayashi, H. 1993. pp. 493-496. In: Front. Photobiol (Shima, A. ed.), Elsevier Science Publishers B. W. Amsterdam.

18. Pass, H. I. 1993. J. Natl. Cancer Inst. 85: 443-447.

19. Roberts, W. G., Klein, M. K., Loomis, M., Weldy, S. and Berns, M. W. 1991. J. Natl. Cancer Inst. 83: 18-23.

20. Takemura, T., Nakajima, S. and Sakata, I. 1994. Photochem. Photobiol. 59: 366-370. 